\title{
Studi Komparatif Ornamen Rumah Adat Lampung Studi Kasus: Rumah Adat Lampung Saibatin Lampung Barat
}

\author{
Endang Setiawati ${ }^{1 *}$, Haris Murwadi ${ }^{2}$ \\ ${ }^{1}$ Mahasiswa, Program Studi Arsitektur, Universitas Bandar Lampung \\ ${ }^{2}$ Dosen, Program Studi Arsitektur, Universitas Bandar Lampung \\ *Penulis Korespondensi: endang.setiawati.11223@gmail.com; Telp. +62 858-0531-9262
}

\begin{abstract}
Abstrak:
Penelitian ini bertujuan untuk mengetahui perbedaan material yang ada pada rumah adat Lampung Saibatin, mengetahui perbedaan bentuk ornamen yang ada pada rumah adat Lampung Saibatin dan untuk mengetahui perbedaan tata ruang yang digunakan pada rumah adat Lampung Saibatin. Penelitian ini menggunakan metode kualitatif dengan metode pengumpulan data, yaitu: studi literatur, pengamatan atau observasi, dokumentasi dan wawancara. Penelitian ini menggunakan Analisis komperatif, yang dilakukan dalam penelitian ini yaitu dengan membandingkan setiap rumah yang telah diteliti. Cara membandikan penelitian yang di dapat yaitu dengan cara mengurutkan usia rumah, lalu membuat keterangan gambar analisis yang di bandingkan. Hasil penelitian menemukan bahwa ornamen rumah adat Lampung Barat memiliki bentuk fauna, flora, perlambangan, wajik dan terdapat juga kaligrafi. Ornamen bentuk fauna biasanya digunakan pada bagian tangga dan penutup balok lantai, hewan yang digunakan berbentuk seperti kadal yang berjumlah dua ekor. Ornamen bentuk flora yang paling sering di gunakan setiap rumah, bentuknya seperti kembang teratai dan jenis kembang yang lain, jenis ornamen ini digunakan pada Lamban Gedung Dalom, Lamban Pesagi dan Lamban kejayaan. Ornamen perlambangan digunakan pada Lamban Gedung Dalom bentuknya melamangkan mahkota kerajaan, ornamen ini digunakan baik pada bagian atau maupun pada bagian interior dan alat-alat musik yang digunakan. Bentuk ornamen wajik ditemukan pada Lamban Dalom dan Lamban Pesagi, namun pada Lamban Dalom perwujudannya masih seperti motif tumbuhan namun bentukya wajik dan pada Lamban Pesagi menggunakan bentuk wajik pada bagian ornamen ujung ander. Ornamen bentuk kaligrafi ditemukan pada Lamban Gedung Dalom, lamban ini juga di temulan motif matahari dan bintang.
\end{abstract}

Kata Kunci: Rumah Tradisional; Lampung Barat; Ornamen.

\section{Latar Belakang}

Lampung adalah sebuah provinsi yang berada paling ujung pulau Sumatera. Lampung adalah salah satu provinsi yang memiliki kebudayaan yang sangat kaya dan beragam. Masyarakat Lampung dibagi menjadi dua kelompok adat besar yaitu masyarakat yang menganut Adat Pepadun dan masyarakat yang menganut adat Saibatin. Bentuk arsitektur rumah adat Lampung mempunyai karakteristik adat kebudayaan yang khas. Rumah Adat Lampung memiliki elemen-elemen dan ragam hias pada ornamen dan tata ruang yang memiliki arti penting dalam kehidupan masyarakat Lampung.

Generasi muda sudah terpengaruh oleh budaya-budaya luar dan banyak generasi muda sekarang tidak mengetahui makna dari budaya itu sendiri. Karena mereka sudah tidak terlalu memikirkan budaya yang ada, akibatnya budaya yang ada terancam keberadaannya atau bahkan punah karena sudah tidak ada lagi yang melestarikan budaya tersebut, tidak hanya budayanya saja namun dalam arsitektur tradisional sudah jarang di temui.

Arsitektur Tradisional yang berada di daerah Lampung Barat semakin memprihatinkan dengan kondisi rumah yang semakin sedikit, hal ini menandakan terancamnya kekayaan yang telah diwariskan dari nenek moyang yang memiliki jenis bangunan dan ornamen unik. Penelitian mengenai ornament budaya lampung ini perlu dilakukan karena melihat kondisi rumah adat yang ada di daerah Lampung Barat jumlahnya semakin sedikit, kurangnya kesadaran masyarakat pentingnya menjaga kebudayaan yang telah diwariskan. Namun, sebagian besar masyarakat berfikiran bahwa pembangunan rumah modern lebih baik dari pada rumah adat tidak sesuai dengan perkembangan zaman dan masih kurangnya informasi yang dibutuhkan. Temuan penelitian sebelumnya membahas makna pada elemen ukir pada bangunan tradisional. Temuan ini terdapat pada Penelitian Adiatmono (2013), Usop (2014), Sianipar dkk (2015), dan Zamad \& Alfiah (2017).

Oleh karena itu, penelitian ini perlu dilakukan untuk pembelajaran dan dokumentasi bagi warisan bangsa. Penelitian ini sudah pernah dilakukan dengan objek Lamban Pesagi tetapi penelitian sebelumnya belum 
dilakukan secara detail. Sehingga, penelitian ini perlu dilakukan untuk menyempurnakan penelitian yang pernah dilakukan sebelumnya.

\section{Metode}

Penelitian ini menggunakan metode kualitatif. Penelitian kualitatif diawali mulai dari lapangan yaitu peneliti terjun langsung ke lapangan, mempelajari suatu proses penemuan yang sedang terjadi secara alami dengan mencatat, menganalisis, melaporkan dan menarik kesimpulan dari proses berlangsungnya penelitian tersebut. Alasanya mengapa memakai metode kualitatif karena metode ini lebih efektif digunakan dalam penelitian ini.

\subsection{Metode Pengumpulan Data}

Metode penelitian ini memiliki beberapa tahapan, sebelum melakukan observasi lapangan maka yang harus dilakukan mencari studi literatur. Studi literatur disebut dengan kajian pustaka, sebelum melakukan penelitian maka harus mencari literatur-literatur baik jurnal maupun buku yang sesuai dengan pembahasan.

Pengamatan atau Observasi adalah aktivitas terhadap suatu proses atau objek dengan maksud merasakan dan kemudian memahami pengetahuan dari sebuah fenomena berdasarkan pengetahuan dan gagasan yang sudah diketahui sebelumnya, untuk mendapatkan informasi-informasi yang dibutuhkan untuk melanjutkan suatu penelitian.

Dokumentasi adalah proses pengumpulan data pada saat penelitian berlangsung baik berupa gambar atau foto, sketsa dan vidio. Tidak hanya pengumpulan data dokumentasi juga akan melalui proses penyimpanan informasi, pemilihan dan pengolahan informasi dibidang pengetahuan. Pada penelitian ini dokumentasi yang dilakukan yaitu mengambil vidio dan foto.

Wawancara yang dilakukan dengan cara mengajukan pertanyaan kepada narasumber untuk mendapatkan informasi yang dibutuhkan secara mendalam. Adapun jenis wawancara yang digunakan dalam penelitian ini yaitu wawancara terpimpin. Wawancara terpimpin yaitu jenis wawancara yang sebelumnya dituntut untuk menyiapkan daftar pertanyaan yang akan ditanyakan. Jenis wawancara ini bertujuan agar pertanyaan bisa dikendalikan dan hasil data-data wawancara sesuai dengan kebutuhan. Adapun bangunan rumah yang dipilih antara lain:

1. Lamban Pesagi di desa Kenali, Kecamatan Belalau, Kabupaten Lampung Barat.

2. Lamban Gedung Dalom, Kerajaan Sekala Brak, Belalau, Kabupaten Lampung Barat.

3. Lamban Sakura di desa Kembahang Tuha, Kabupaten Lampung Barat.

4. Lamban Dalom di desa Kembahang, Kabupaten Lampung Barat.

\subsection{Metode Analisis Data}

Analisis komperatif merupakan analisis yang dilakukan dalam penelitian ini yaitu dengan membandingkan setiap rumah yang telah diteliti. Analisis ini membandingkan kolom, pintu, jendela, lantai, dinding, plafon, lisplang, ornamen kolo, ornamen pagar, onamen pintu, ornamen jendela, ornamen dinding dan ornamen lisplang pada Lamban Gedung Dalom, Lamban Pesagi, Lamban Kejayaan, Lamban Sakura dan Lamban Dalom. Cara membandikan penelitian yang di dapat yaitu dengan cara membuat tabel dengan mengurutkan usia rumah, lalu membuat keterangan gambar analisis yang di bandingkan. Tujuan dari analisis ini yaitu untuk mendapatkan persamaan, perbedaan dan hasil analisis data.

\section{Hasil dan Pembahasan}

\subsection{Analisis Ornamen Kolom Bagian Beranda}

Analisis ornamen kolom bagian beranda pada Rumah Gedung Dalom, Lamban Pesagi, Lamban Kejayaan, Lamban Sakura dan Lamban Dalom, yaitu: 
Tabel 1. Perbedaan Ornamen Kolom

\begin{tabular}{|c|c|c|c|c|}
\hline R.GEDUNG DALOM & R.PESAGI & R.KEJAYAAN & R. SAKURA & LAMBAN DALOM \\
\hline 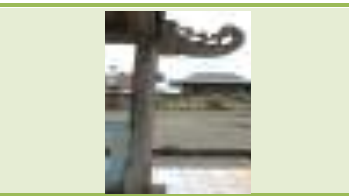 & $\begin{array}{l}\text { (tidak memiliki } \\
\text { kolom bagian } \\
\text { beranda) }\end{array}$ & 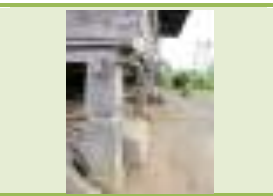 & $=$ & $-1=$ \\
\hline \multicolumn{5}{|c|}{ KETERANGAN } \\
\hline $\begin{array}{l}\text { Kolom berandan } \\
\text { memiliki ukiran penuh } \\
\text { pada bagian kolomnya. } \\
\text { Pada bagian kolom } \\
\text { paling ujung dihiasi } \\
\text { oleh sebuah ornamen } \\
\text { yang sama dengan } \\
\text { rumah adat pesagi. }\end{array}$ & $\begin{array}{l}\text { Rumah pesagi ini } \\
\text { memiliki kolom } \\
\text { yang berbentuk } \\
\text { unik namun } \\
\text { kolom ini tidak } \\
\text { memiliki } \\
\text { ornamen. } \\
\text { Bentukya hampir } \\
\text { sama dengan } \\
\text { rumah yang } \\
\text { pertama. }\end{array}$ & $\begin{array}{l}\text { Kolom ini } \\
\text { merupakan kolom } \\
\text { bagian beranda } \\
\text { rumah. bentuknya } \\
\text { lebih kecil dari } \\
\text { kolom yang } \\
\text { nomor dua. } \\
\text { Memiliki bentuk } \\
\text { yang sederhana. }\end{array}$ & $\begin{array}{l}\text { Kolom ini } \\
\text { merupakan kolom } \\
\text { pada bagian } \\
\text { beranda. Memiliki } \\
\text { bentuk yang lebik } \\
\text { unik dari pada } \\
\text { bentuk kolom dua. } \\
\text { Ukuranya pun lebih } \\
\text { kecil dari kolom } \\
\text { dua. }\end{array}$ & $\begin{array}{l}\text { Kolom ini merupakan } \\
\text { kolom bagian } \\
\text { beranda yang tidak } \\
\text { memiliki ornamen, } \\
\text { hanya terdapat motif } \\
\text { pasangan bata dari } \\
\text { material acian semen. }\end{array}$ \\
\hline
\end{tabular}

Lamban Pesagi hanya memiliki satu jenis bentuk kolom, ini dikarenakan rumah ini tidak memiliki beranda, berbeda dengan rumah yang lain memiliki dua sampai tiga jenis kolom.

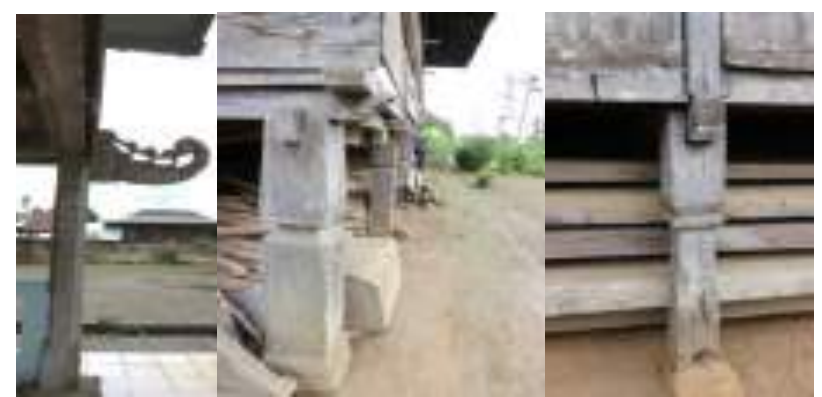

Gambar 1. Ornamen Tiang Beranda Lamban Gedung Dalom, Lamban Kejayaan Dan Lamban Sakura

Bagian kolom beranda bentuknya lebih kecil ini karena pada beranda tidak memiliki banyak aktifitas dan tidak memiliki banyak beban sedangkan dalam segi ornamen, kolom ini lebih terlihat menarik karena posisi kolom ini berada pada bagian depan sehingga bentuknya harus lebih indah.

\subsection{Analisis Ornamen Kolom Bagian Tengah}

Analisis ornamen kolom pada Rumah Gedung Dalom, Lamban Pesagi, Lamban Kejayaan, Lamban Sakura dan Lamban Dalom, yaitu:

Tabel 2. Analisis Ornamen Kolom Bagian Tengah

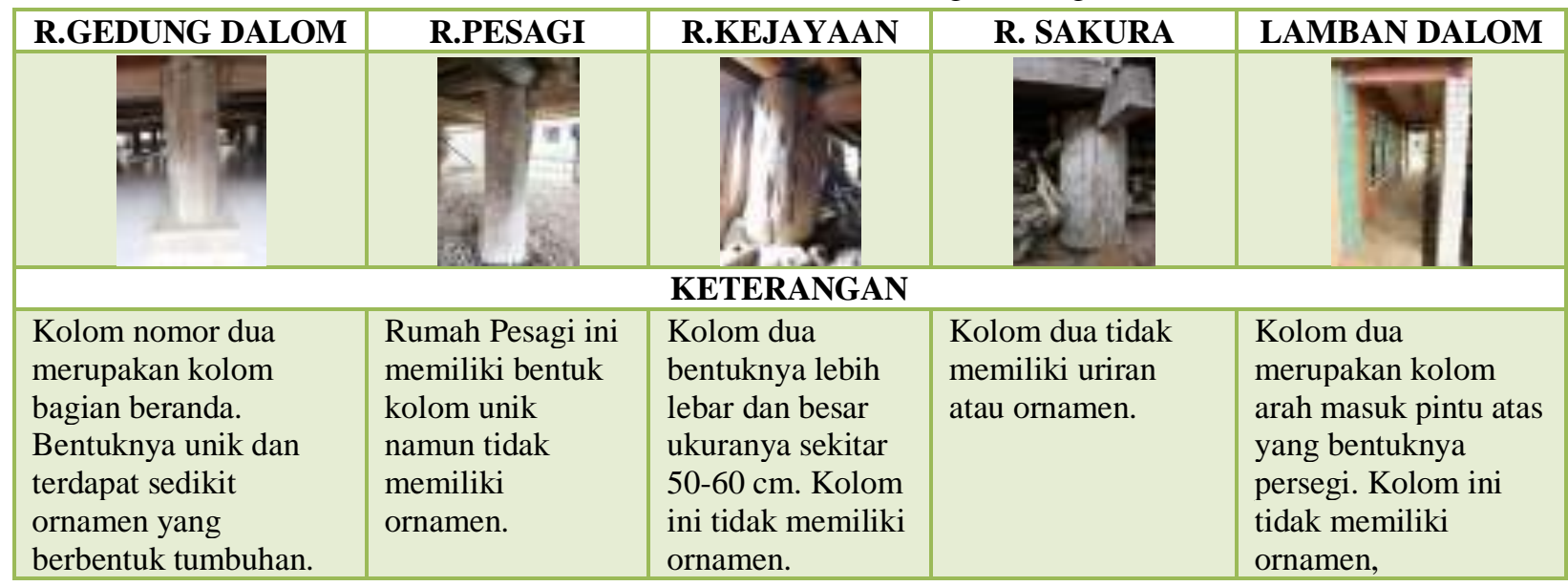




\subsection{Analisis Ornamen Jendela}

Analisis ornamen jendela pada Rumah Gedung Dalom, Lamban Pesagi, Lamban Kejayaan, Lamban Sakura dan Lamban Dalom, yaitu:

Tabel 3. Perbedaan Ornamen Jendela

\begin{tabular}{|c|c|c|c|c|}
\hline R.GEDUNG DALOM & R.PESAGI & R.KEJAYAAN & R. SAKURA & LAMBAN DALOM \\
\hline & Ney & silis that & Phan & $\frac{54}{4}$ \\
\hline \multicolumn{5}{|c|}{ KETERANGAN } \\
\hline $\begin{array}{l}\text { Rumah ini memiliki } \\
\text { ornamen pada bagian } \\
\text { jendelanya yaitu tralis } \\
\text { yang teruat dari } \\
\text { material kayu. Interior } \\
\text { dalam rumah pada } \\
\text { bagian atas jendela } \\
\text { memili ukiran yang } \\
\text { terbuat dari papan kayu } \\
\text { yang diukir. Jenis } \\
\text { jendela yaitu jendela } \\
\text { krapyak. }\end{array}$ & $\begin{array}{l}\text { Rumah ini } \\
\text { memiliki } \\
\text { beberapa jendela } \\
\text { namun ini bukan } \\
\text { hanya untuk } \\
\text { pencahayaan atau } \\
\text { pertukaran udara } \\
\text { namun sebagai } \\
\text { ornamen pada } \\
\text { rumah. }\end{array}$ & $\begin{array}{l}\text { Rumah ini } \\
\text { memiliki } \\
\text { beberapa pintu } \\
\text { tetapi tidak } \\
\text { memiliki } \\
\text { ornamen. }\end{array}$ & $\begin{array}{l}\text { Jendela Rumah ini } \\
\text { tidak memiliki } \\
\text { ornamen hanya } \\
\text { dibawah jendela } \\
\text { yang berbentuk } \\
\text { sederhana. Jenis } \\
\text { jendela yaitu } \\
\text { jendela krapyak. }\end{array}$ & $\begin{array}{l}\text { Jendela rumah ini } \\
\text { sudah memakai } \\
\text { material kaca. Dan } \\
\text { dibawah jendela } \\
\text { terdapat ornamen } \\
\text { yang ditempel } \\
\text { menggunakan paku } \\
\text { besi. Rumah ini } \\
\text { sudah menggunakan } \\
\text { cat yang berwarna } \\
\text { hijau kuning. }\end{array}$ \\
\hline
\end{tabular}

Jendela Lamban Gedung Dalom dan Lamban Sakura sudah menggunakan jendela krapyak. Ornamen Jendela Lamban Gedung Dalom memiliki tralis yang berbentuk seperti catur dengan material kayu, ornamen ini sudah tercampur dengan kebudayaan lain. Bentuk jendela rumah lampung masih ada yang mempertahankan dengan dua daun jendela.

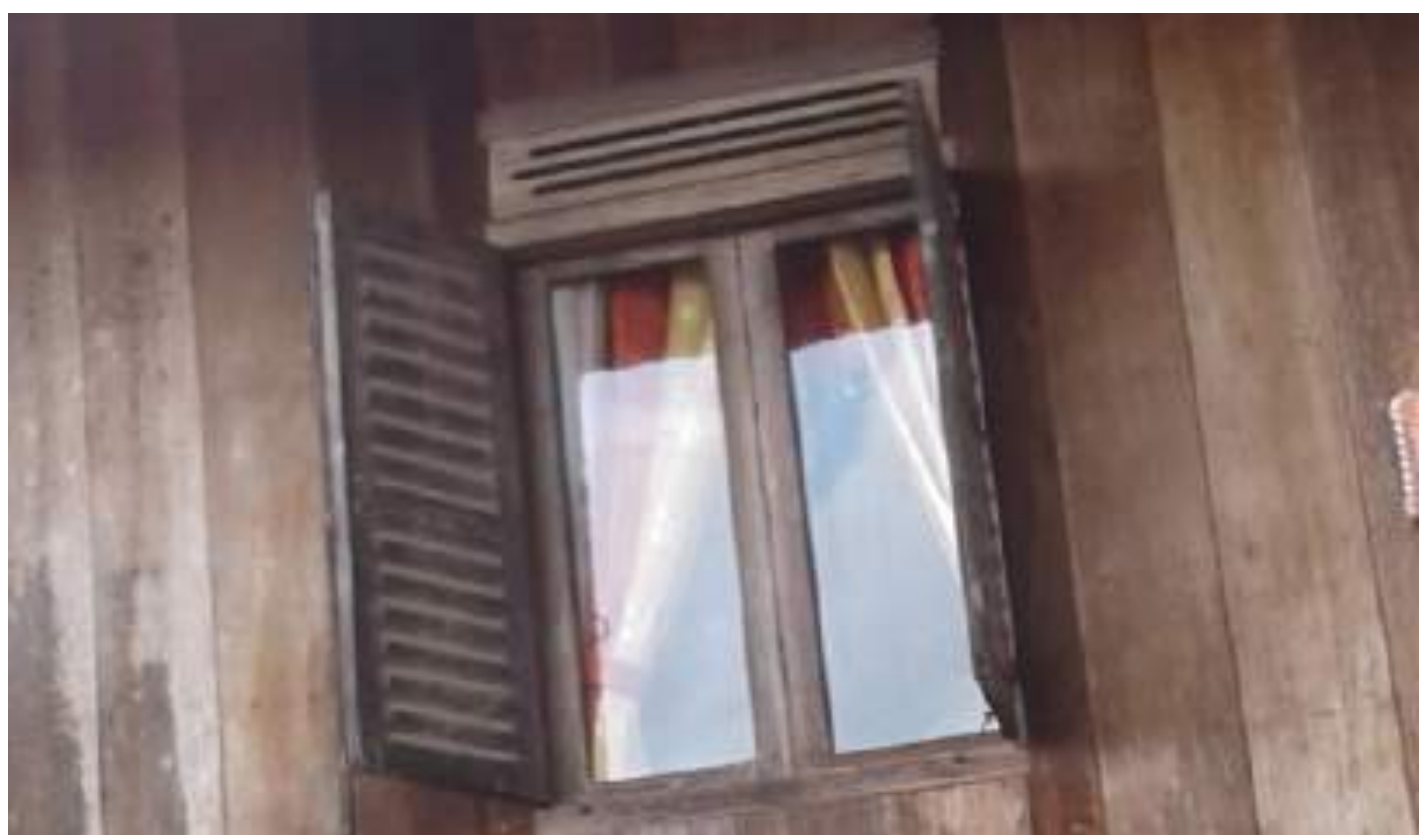

Gambar 2. Bentuk Jendela Lamban Modern

Foto diatas merupakan bentuk jendela rumah lampung yang lebih modern, jendelanya berbentuk krapyak dan sudah memiliki ventilasi udara.

\subsection{Analisis Ornamen Pintu Utama}

Analisis ornamen pintu pada Rumah Gedung Dalom, Lamban Pesagi, Lamban Kejayaan, Lamban Sakura dan Lamban Dalom yaitu: 
Tabel 4. Perbedaan Ornamen Pintu

\begin{tabular}{|l|l|l|l|l|}
\hline R.GEDUNG DALOM & R.PESAGI & R.KEJAYAAN & R. SAKURA & LAMBAN DALOM \\
\hline & & & & \\
\hline
\end{tabular}

Pintu Lamban Gedung Dalom pada bagian atasnya memiliki motif yang sama pada sarung terapang atau punduk. Dalam kris ini ditemukan motif yang berbentuk bunga teratai.
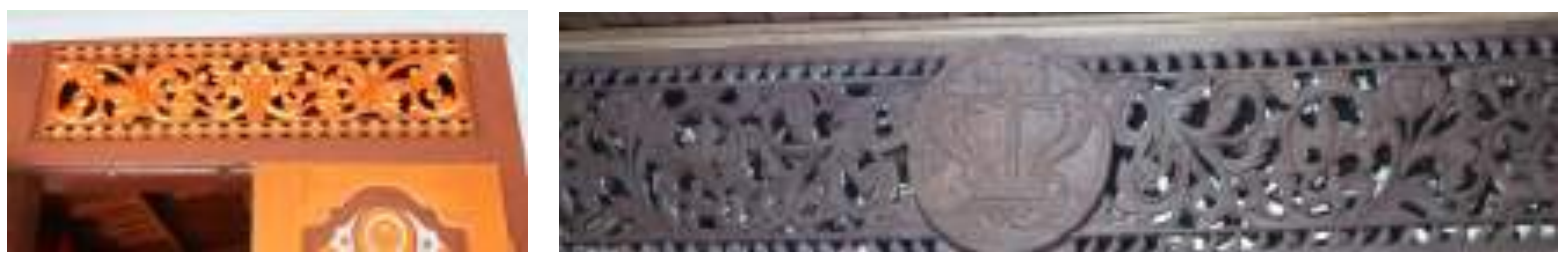

Gambar 3. Ornamen Kembang Teratai Di Lamban Gedung Dalom

Tidak hanya bagian pintu namun pada bagian interior bagunan terdapat motif bunga teratai. Motif ini sama dengan baju pengantin wanita pada bagian bebe yang memiliki motif bunga teratai. Bagian pintu lamban pesagi memiliki ornamen pintu pada bagian atas dan pada bagian samping. Untuk bagian atas menggunakan ukiran yang berbentuk tumbuhan. Motinya seperti bunga yang ada pada lamban gedung dalom.
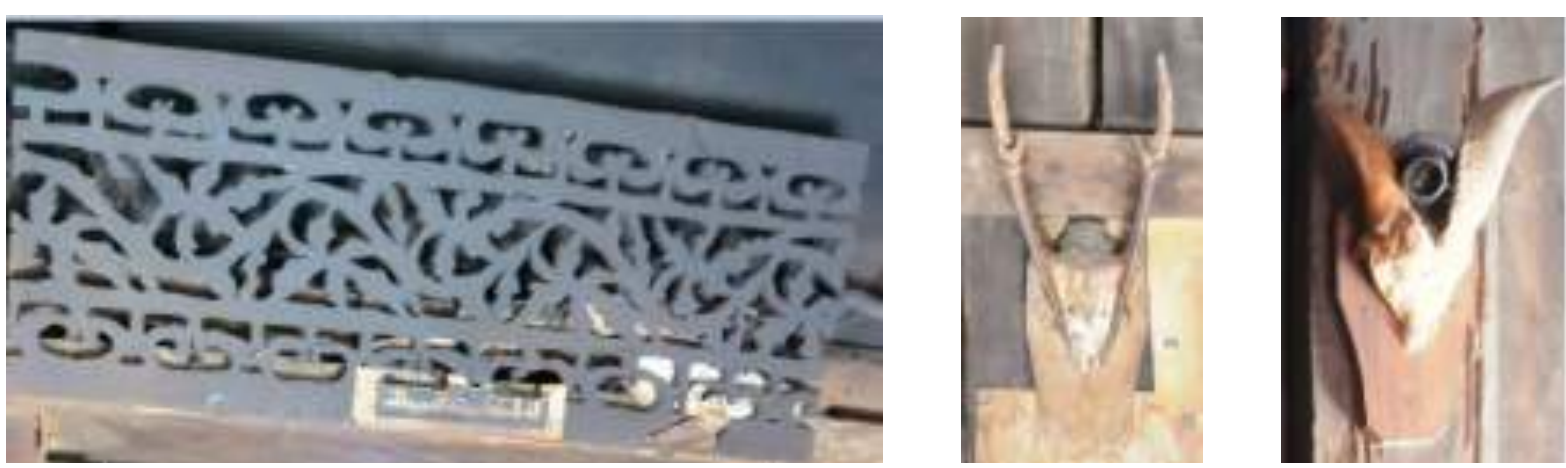

Gambar 4. Ornamen Tumbuhan Dan Kepala Rusa Pada Pintu Lamban Pesagi

Untuk ornamen pada rumah kejayaan merupakan penamaan rumah yang diberi langsung oleh sultan kerajaan adat skala brak. Ornamen pintu masuk sultan yang berada diatas memiliki ornamen kapal. Ornamen pintu ini memili ornamen kapal, untuk bagian pintu memiliko ornamen yang berbentuk 

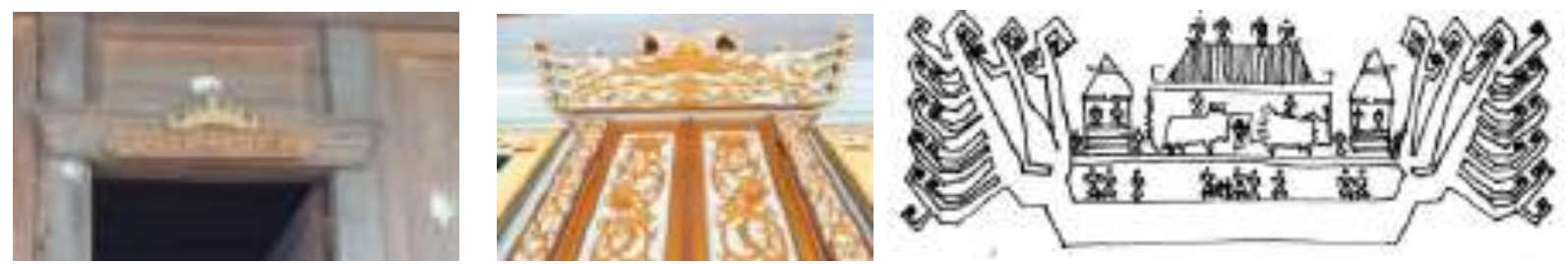

Gambar 5. Ornamen Siger Dan Kapal Pada Lamban Kejayaan Dan Lamban Gedung Dalom

\subsection{Analisis Ornamen Atap}

Analisis ornamen atap pada Rumah Gedung Dalom, Lamban Pesagi, Lamban Kejayaan, Lamban Sakura dan Lamban Dalom, yaitu:

Tabel 5. Perbedaan Ornamen Atap

\begin{tabular}{|l|c|c|c|c|}
\hline R.GEDUNG DALOM & R.PESAGI & R.KEJAYAAN & R. SAKURA & LAMBAN DALOM \\
\hline & (tidak ada) & (tidak ada) & \\
\hline $\begin{array}{l}\text { Rumah ini memiliki } \\
\text { ornamen pada bagian } \\
\text { atapnya yang dikenal } \\
\text { sebagai Khawik Butoh. }\end{array}$ & $\begin{array}{l}\text { Ornamen pada } \\
\text { atap rumah ini } \\
\text { berna culu langi. }\end{array}$ & $\begin{array}{l}\text { Rumah ini tidak } \\
\text { memiliki ornamen } \\
\text { pada bagian atap. }\end{array}$ & $\begin{array}{l}\text { Rumah ini tidak } \\
\text { memiliki ornamen } \\
\text { pada bagian atap. }\end{array}$ & $\begin{array}{l}\text { Memiliki ornamen } \\
\text { yang berbentuk siger } \\
\text { yang berwarna } \\
\text { kuning dengan bahan } \\
\text { yang riang. }\end{array}$ \\
\hline
\end{tabular}

Rumah gedung dalom memiliki ornamen pada bagian atas atap yang bentuknya sama pada gambar ornamen bagian dalam rumah. bentuknya seperti mahkota raja seperti perlambangan rumah milik raja.
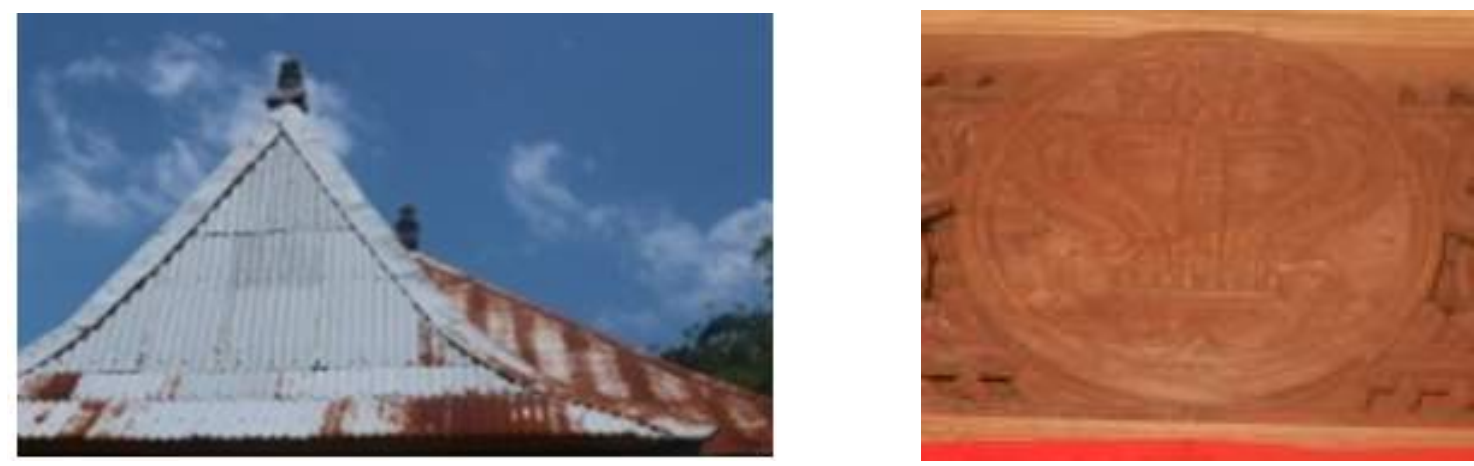

Gambar 6. Lambang Kerajaan Skala Brak Pada Ujung Atap Dan Ornamen Interior Bangunan

\subsection{Analisis Ornamen Dinding}

Analisis ornamen dinding pada Rumah Gedung Dalom, Lamban Pesagi, Lamban Kejayaan, Lamban Sakura dan Lamban Dalom, yaitu: 
Tabel 6. Perbedaan Ornamen Dinding

\begin{tabular}{|l|c|c|c|c|}
\hline R.GEDUNG DALOM & R.PESAGI & R.KEJAYAAN & R. SAKURA & LAMBAN DALOM \\
\hline & (tidak ada) & (tidak ada) & (tidak ada) & \\
\hline & & & \\
\hline
\end{tabular}

Dinding gedung dalom ukirannya sama dengan ukiran tiang, pada bagian dinding terlihat sudah pernah direnovasi karena bentuk papan yang berukuran lebih kecil. Lamban dalom memiliki ornamen pada bagian dinding dengan bentuk wajik, namun berbentuk bunga yang mekar. Ditemukan motif wajik pada paguk Lamban Pesagi.

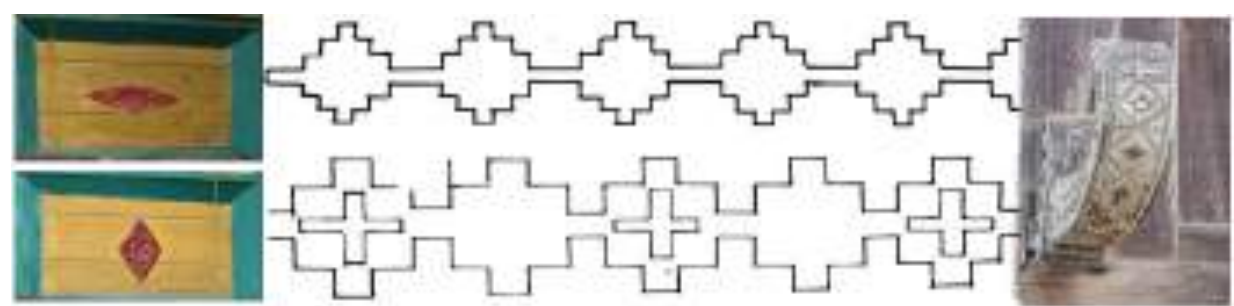

Gambar 7. Motif Wajik Pada Lamban Dalom Dan Lamban Pesagi

\subsection{Analisis Ornamen Pagar}

Analisis ornamen pagar pada Rumah Gedung Dalom, Lamban Pesagi, Lamban Kejayaan, Lamban Sakura dan Lamban Dalom, yaitu:

Tabel 7. Perbedaan Ornamen Pagar

\begin{tabular}{|l|c|c|c|c|}
\hline R.GEDUNG DALOM & R.PESAGI & R.KEJAYAAN & R. SAKURA & LAMBAN DALOM \\
\hline & (tidak ada) & (tidak ada) & & \\
\hline
\end{tabular}


Lamban Gedung Dalom memiliki ornamen pagar berbentuk bunga teratai, seperti ornamen pada pintu dan pada bagian interior bangunan. Motif bunga ini dimiliki juga pada pakaian pengantin wanita lampung pada bagian bebenya.
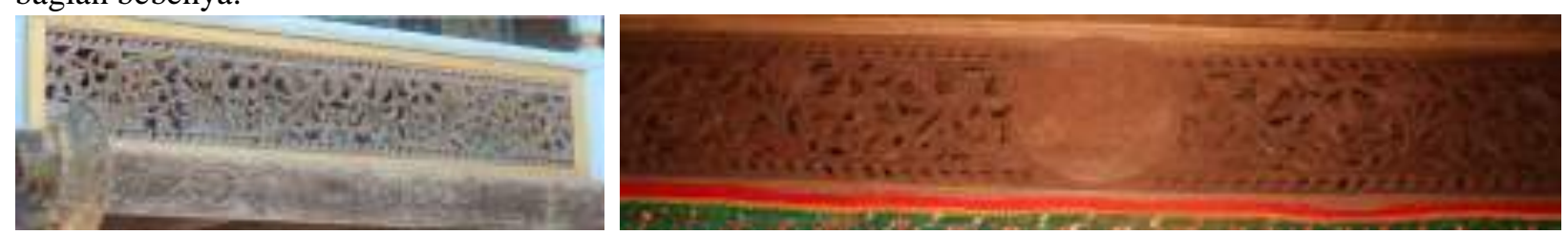

Gambar 8. Ornamen Bunga Teratai Pada Lamban Gedung Dalom

Tidak semua bangunan memiliki ornamen pagar seperti Rumah Gedung Dalom, bentuk ornamen pada rumah ini hampir keseluruhanya memakai motif kembang teratai, untuk rumah masyarakat sekarang tidak terlalu menggunakan banyak ornamen karena masyarakat lebih menekankan kefungsi bangunan, untuk membuat ornamen atau ukiran memerlukan biaya yang tidak sedikit.

\subsection{Analisis Ornamen Tiang Bagian Luar Bangunan}

Analisis ornamen tiang pada Rumah Gedung Dalom, Lamban Pesagi, Lamban Kejayaan, Lamban Sakura dan Lamban Dalom, yaitu:

Tabel 8. Perbedaan Ornamen Tiang

\begin{tabular}{|l|l|l|l|l|}
\hline R.GEDUNG DALOM & \multicolumn{1}{|c|}{ R.PESAGI } & R.KEJAYAAN & R. SAKURA & LAMBAN DALOM \\
\hline \multicolumn{1}{|c|}{} & $\begin{array}{l}\text { (tidak memiliki } \\
\text { ornamen tiang) }\end{array}$ & $\begin{array}{l}\text { (tidak memiliki } \\
\text { ornamen tiang) }\end{array}$ & \\
\hline & & & & \\
\hline
\end{tabular}

Lamban Gedung Dalom memiliki beberapa macam dinding yang memiliki ukiran unik. Menurut hasil wawancara yang dilakukan, tidak ada yang bisa meniru ukiran atau ornamen yang ada pada rumah ini.
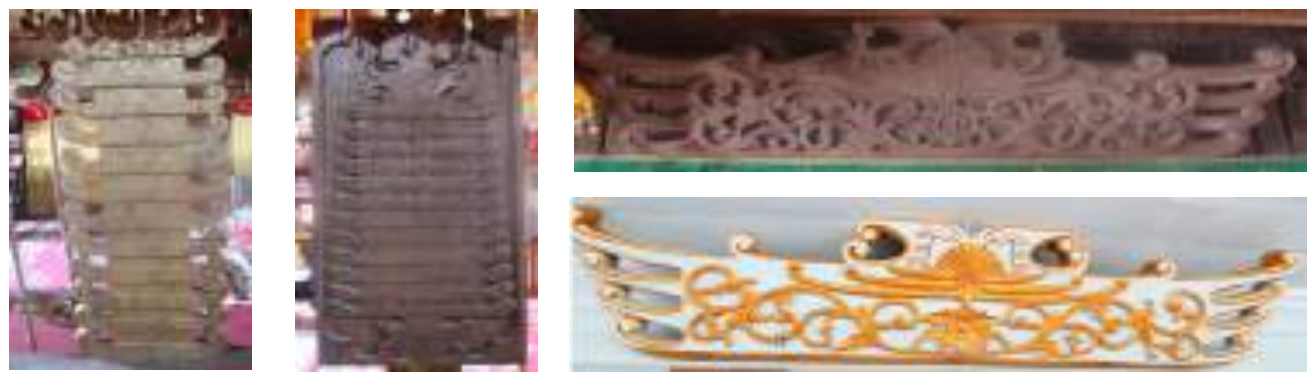
Gambar 9. Ornamen Kapal Pada Lamban Gedung Dalom

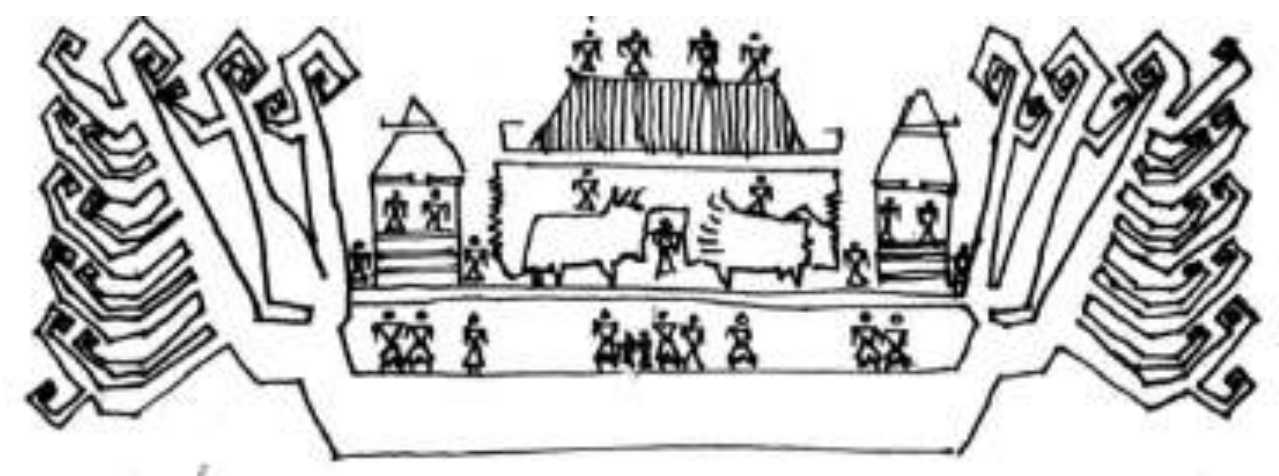

Gambar 10. Sketsa Motif Kapal Yang Ada Pada Kain Pelepai

Pada bagian ruang berkumpul terdapat tiang yang berbentuk perahu dan terdapat ornamen perahu pada bagian dalam maupun luar bangunan. Bentuk perahu ini hampir sama dengan motif kain pelepai yang terdapat motif perahu. Rumah kejayaan memiliki tiang yang memiliki bentuk unik yang disebut dengan Sangai Batin tiang ini digunakan sebagai acara saat ada pengantin yang baru dinikahkan lalu mereka diharuskan menyenderkan badan merka ditiang tersebut dalam posisi duduk dan saling membelakangi.

\subsection{Analisis Ornamen Tiang Bagian dalam Bangunan}

Analisis Ornamen Tiang Bagian dalam Bangunan pada Rumah Gedung Dalom, Lamban Pesagi, Lamban Kejayaan, Lamban Sakura dan Lamban Dalom, yaitu:

Tabel 9. Ornamen Tiang Bagian dalam Bangunan

\begin{tabular}{|c|c|c|c|c|}
\hline R.GEDUNG DALOM & R.PESAGI & R.KEJAYAAN & R. SAKURA & LAMBAN DALOM \\
\hline & $\begin{array}{l}\text { (tidak memiliki } \\
\text { ornamen bagian } \\
\text { dalam bangunan) }\end{array}$ & $=$ & $\begin{array}{l}\text { (tidak memiliki } \\
\text { ornamen bagian } \\
\text { dalam bangunan) }\end{array}$ & $\begin{array}{l}\text { (tidak memiliki } \\
\text { ornamen bagian } \\
\text { dalam bangunan) }\end{array}$ \\
\hline \multicolumn{5}{|c|}{ KETERANGAN } \\
\hline $\begin{array}{l}\text { merupakan tiang } \\
\text { bagian dalam ruangan } \\
\text { yang ukirannya yang } \\
\text { unik.Nomor lima } \\
\text { merupakan tiang yang } \\
\text { memiliki lebar seperti } \\
\text { papan namun } \\
\text { teksturnya keras dan } \\
\text { tiang ini menghadap } \\
\text { lurus dengan ornamen } \\
\text { lafal kaligrafi dan } \\
\text { ornamen bunga yang } \\
\text { menembus papan. }\end{array}$ & $\begin{array}{l}\text { Rumah ini tidak } \\
\text { memiliki ornamen } \\
\text { pada bagian tiang. }\end{array}$ & $\begin{array}{l}\text { Rumah ini } \\
\text { memiliki tingan } \\
\text { yang memiliki } \\
\text { ornamen dan } \\
\text { fungsi } \\
\text { kebudayaan } \\
\text { pengantin. Tiang } \\
\text { ini disebut dengan } \\
\text { Sangai Batin } \\
\text { tiang. }\end{array}$ & $\begin{array}{l}\text { Rumah ini tidak } \\
\text { memiliki ornamen } \\
\text { pada bagian tiang. }\end{array}$ & $\begin{array}{l}\text { Rumah ini tidak } \\
\text { memiliki ornamen } \\
\text { pada bagian tiang. }\end{array}$ \\
\hline
\end{tabular}

\subsection{Analisis Ornamen Tangga}

Analisis ornamen tangga pada Rumah Gedung Dalom, Lamban Pesagi, Lamban Kejayaan, Lamban Sakura dan Lamban Dalom, yaitu: 
Tabel 10. Perbedaan Ornamen Tangga

\begin{tabular}{|c|c|c|c|c|}
\hline R.GEDUNG DALOM & R.PESAGI & R.KEJAYAAN & R. SAKURA & LAMBAN DALOM \\
\hline$|Z|$ & $\begin{array}{l}\text { (Tidak Memiliki } \\
\text { Ornamen) }\end{array}$ & & & \\
\hline \multicolumn{5}{|c|}{ KETERANGAN } \\
\hline $\begin{array}{l}\text { Ornamen pada bagian } \\
\text { tangga dan pagar } \\
\text { tangganya. Pada bagian } \\
\text { anak tangga memiliki } \\
\text { ornamen bentuk } \\
\text { tumbuhan dan ada yang } \\
\text { hewan seperti bentuk } \\
\text { kadal, matahari juga } \\
\text { terukir pada tangga } \\
\text { rumah ini. Pada bagian } \\
\text { pagar tangga memiliki } \\
\text { ukiran tumbughan yang } \\
\text { unik dan menarik. }\end{array}$ & $\begin{array}{l}\text { Rumah ini tidak } \\
\text { memiliki ornamen } \\
\text { pada bagian } \\
\text { tangganya. } \\
\text { Tangga hanya } \\
\text { sederhana pagar } \\
\text { tangga hanya } \\
\text { berada di bagian } \\
\text { kanan tangga } \\
\text { tampa propil- } \\
\text { propil tangga. }\end{array}$ & $\begin{array}{l}\text { Rumah ini } \\
\text { memiliki ornamen } \\
\text { tangga pada } \\
\text { bagian propil } \\
\text { tiang tangga } \\
\text { bentuknya hampir } \\
\text { sama dengan } \\
\text { kolom bagian } \\
\text { depan beranda. } \\
\text { Sederhana namun } \\
\text { Unik. }\end{array}$ & $\begin{array}{l}\text { Rumah ini tidak } \\
\text { memiliki ornamen } \\
\text { pada bagian } \\
\text { tangganya. }\end{array}$ & $\begin{array}{l}\text { Rumah ini memiliki } \\
\text { ornamen yang } \\
\text { berbentuk seperti } \\
\text { kepala kuda pada } \\
\text { bagian tiang. Dan } \\
\text { terdapat tiang pagar } \\
\text { tangga yang } \\
\text { bentuknya seperti } \\
\text { catur. }\end{array}$ \\
\hline
\end{tabular}

Lamban gedung dalom memiliki ukiran bentuk hewan pada bagian tangganya dan terdapat ukiran tumbuhan yang bentuknya sama dengan ornamen pada sisi pintu. Ornamen ini sampai sekarang tetap dipertahankan untuk menunjukan keindahannya.
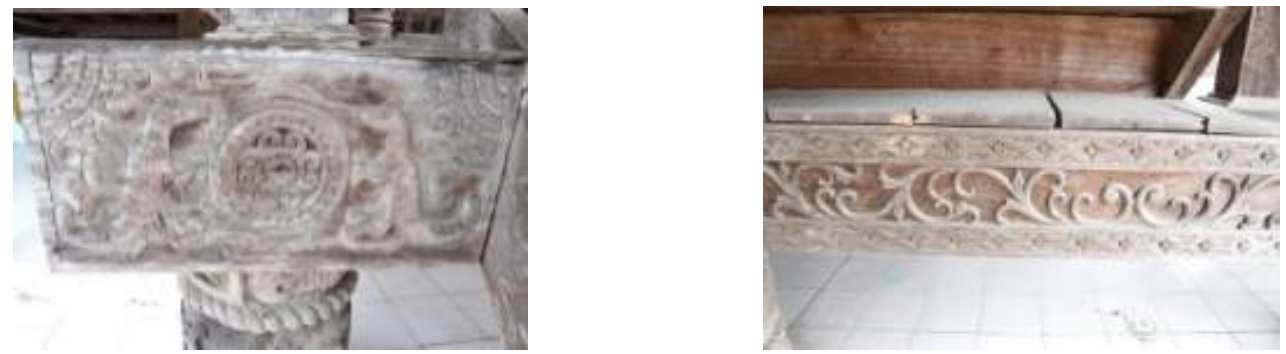

Gambar 11. Ornamen Fauna Dan Flora Pada Lamban Gedung Dalom

Lamban Gedung Dalom Terdapat banyak ukiran dan jenisnya berbeda-beda, namun rumah ditemukan ukiran dengan ukiran yang lebih simple sepertinya ukiran ini lebih lama umurnya dibandingkan ukiran yang lain karena keterbatasan alat dan teknologi yang ada mengakibatkan ukiran yang dibuat sederhana, berikut salah satu contoh ukiran yang berusia lebih tua pada bagian kolom Lamban Gedung Dalom. Dapat dikatakan bahwa lamban gedung dalom pada bagian ornamen tangga sudah mengalami penambahan dan sudah memakai alat dan teknologi yang lebih modern.
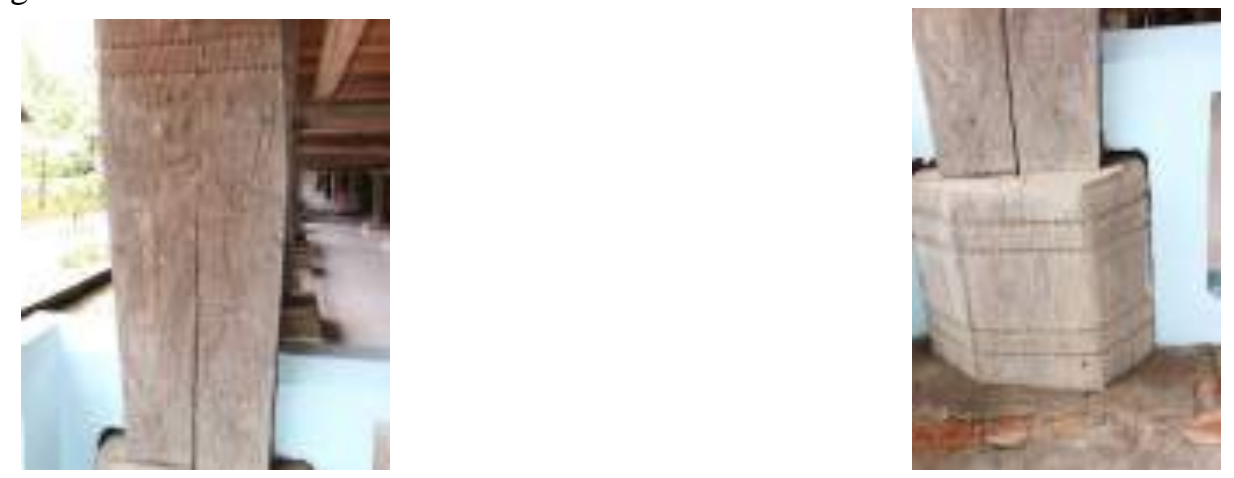

Gambar 12. Ornamen Lama Pada Lamban Gedung Dalom 


\subsection{Analisis Ornamen Rangka Lantai}

Analisis ornamen rangka lantai pada Rumah Gedung Dalom, Lamban Pesagi, Lamban Kejayaan, Lamban Sakura dan Lamban Dalom, yaitu:

Tabel 11. Perbedaan Ornamen Rangka Lantai

\begin{tabular}{|l|l|l|l|l|}
\hline R.GEDUNG DALOM & \multicolumn{1}{|c|}{ R.PESAGI } & R.KEJAYAAN & R. SAKURA & LAMAN DALOM \\
\hline & & & \\
\hline
\end{tabular}

Perbedaan pada bagian ornamen rangka lantai kelima rumah tersebut, yaitu Pada bagian ornamen rangka lantai pada Rumah Gedung Dalom dan Lamban Dalom ini memiliki persamaan yaitu bukan rangka lantai yang memiliki ornamen tetapi pada bagian penutup rangka lantai bagian depan yang memiliki ornamen, namun ornamen rangka lantai pada Rumah Gedung Dalom lebih memiliki ornamen yang sangat detai dari brntuk tumbuhan, hewan dan alam. Pada bagian ornamen rangka lantai pada Lamban Pesagi dan Lamban Kejayaan memiliki persamaan yaitu sama-sama memiliki ornamen bentuk, namun pada lamban pesagi ornamen yang ditemukan berada di sisi bawah. Lamban kejayaan memiliki ornamen bentuk rangka lantai pada bagian ujungnya. Lamban sakura tidak memiliki ornamen pada rangka lantai. Hasil analisis data diatas maka akan ditarik kesimpulan bahwa Rumah Gedung Dalom adalah rumah yang memiliki ornamen pada bagian rangka lantai yang paling indah, unik dan kaya bentuk ukiran.

Terlihat dari bentuk dan ukiran yang hanya digores ornamen rangka lantai Lamban Pesagi memiliki ukiran yang paling tua diantara yang lain.
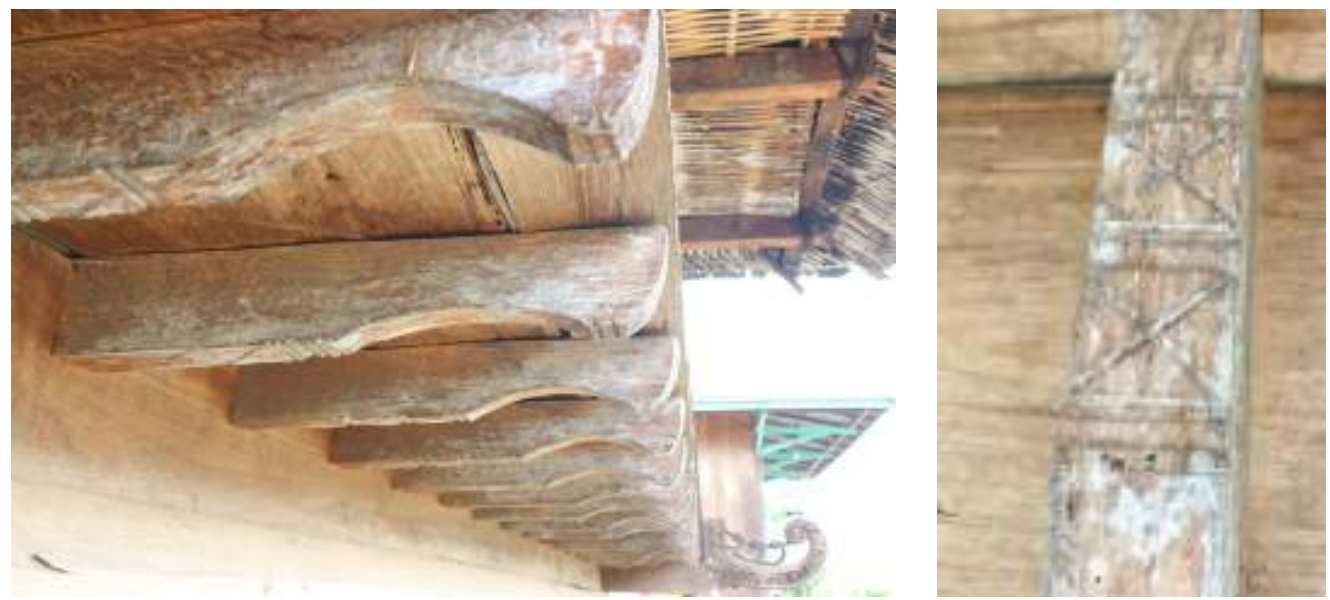

Gambar 13. Ornamen Pada Rangka Lantai Lamban Pesagi 


\section{Kesimpulan}

Kesimpulan penelitian yang telah dilakukan, yaitu ornamen rumah adat Lampung Barat memiliki bentuk fauna, flora, perlambangan, wajik dan terdapat juga kaligrafi. Ornamen bentuk fauna biasanya digunakan pada bagian tangga dan penutup balok lantai, hewan yang digunakan berbentuk seperti kadal yang berjumlah dua ekor. Ornamen bentuk flora yang paling sering digunakan setiap rumah, bentuknya seperti kembang teratai dan jenis kembang yang lain, jenis ornamen ini digunakan pada Lamban Gedung Dalom, Lamban Pesagi dan Lamban kejayaan. Ornamen perlambangan digunakan pada Lamban Gedung Dalom bentuknya melamangkan mahkota kerajaan, ornamen ini digunakan baik pada bagian atau maupun pada bagian interior dan alat-alat musik yang digunakan. Bentuk ornamen wajik ditemukan pada Lamban Dalom dan Lamban Pesagi, namun pada Lamban Dalom perwujudannya masih seperti motif tumbuhan namun bentukya wajik dan pada Lamban Pesagi menggunakan bentuk wajik pada bagian ornamen ujung ander. Ornamen bentuk kaligrafi ditemukan pada Lamban Gedung Dalom, lamban ini juga di temulan motif matahari dan bintang.

\section{Daftar Pustaka}

Adiatmono, Fendi. Soedarsono, R. M. Gustami, S. P. Simatupang G. R. Lono Lastoro (2013). Identitas Ornamen Rumah Tradisional Gorontalo Tahun 1890-2001.

Sianipar, Karolina. Gunardi, Gugun. Widyonugrahanto-, Rustiyanti, Sri. (2015). Makna Seni Ukirangorga Pada Rumah Adat Batak, Volume. 25, Nomor. 3. Bandung. Unpad.

Usop, Tari Budayanti. (2014). Pelestarian Arsitektur Tradisional Dayak Pada Pengenalan Ragam Bentuk Konstruksi Dayak.

Zamad, Nurmiati dan Alfiah, Alfiah (2017). Identitas Arsitektur Mandar Pada Bangunan Tradisional Di Kabupaten Majene, Jurnal Nature Volume. 4, Nomor: 1. 